\title{
Effectiveness of school- and family-based interventions to prevent gaming addiction among grades 4-5 students in Bangkok, Thailand
}

This article was published in the following Dove Press journal:

Psychology Research and Behavior Management

\author{
Nipaporn Apisitwasana ${ }^{1,2}$ \\ Usaneya Perngparn ${ }^{1,3}$ \\ Linda B Cottler ${ }^{4}$ \\ 'College of Public Health Sciences, \\ Chulalongkorn University, Bangkok, \\ Thailand; ' ${ }^{2}$ Department of Community \\ Health Nursing, Boromarajonnani \\ College of Nursing, Bangkok, Thailand; \\ ${ }^{3}$ Drug Dependence Research \\ Center, College of Public Health \\ Sciences, Chulalongkorn University, \\ Bangkok, Thailand; ${ }^{4}$ Department \\ of Epidemiology, College of Public \\ Health and Health Professions and \\ College of Medicine, University of \\ Florida, Gainesville, FL, USA
}

Purpose: This study aimed to assess the effectiveness of Participatory Learning School and Family Based Intervention Program for Preventing Game Addiction by Developing SelfRegulation of gaming addiction among students of grades 4 and 5 in Bangkok.

Methods: A quasi-experimental study was implemented among students of grades 4 and 5 at primary schools in Bangkok selected through multistage random sampling. Two comparable schools were randomly assigned to either the intervention or control group. Then, 310 students in the randomly selected classrooms were allocated to each group. The intervention group received the self-regulation program with school and family involvement to prevent gaming addiction. Master teachers attended in-house training on prevention of gaming addiction in children. Parents of these children received a gaming addiction prevention manual and guidelines. The program lasted 8 weeks. The control group received no intervention. Knowledge and Attitude About Gaming Questionnaire, Game Addiction Screening Test (GAST), and Game Addiction Protection Scale were utilized to assess subjects at baseline, immediately after, and 3 months post-intervention. Descriptive statistics, chi-square, and independent $t$-test were used to describe characteristics of the participants, and repeated measures ANOVA was analyzed to test the effectiveness of the intervention.

Results: The findings revealed that there were significant differences in knowledge, attitude, self-regulation, and gaming addiction behaviors $(p<0.05)$ immediately and 3 months postintervention. Positive effects of the intervention included increase in knowledge, attitude, and self-regulation, whereas the GAST score was significantly decreased $(p<0.05)$ immediately and 3 months after the program.

Conclusion: The program based on self-regulation and school and family participation is effective for preventing gaming addiction in students of grades 4 and 5 in Bangkok, Thailand. Keywords: game addiction, prevent, grade 4-5 students, self-regulation, school-based intervention, family-based intervention

\section{Introduction}

Currently, gaming has become a pervasive part of the lives of Thai youth. Data from the National Statistics Office ${ }^{1}$ indicated that the average computer and Internet usage in Thailand was 3.1 hours per day - the highest of any country in Asia. The age groups most active online were 15 - to 24 -year-olds $(51.9 \%)$ followed by 6 - to 14 -year-olds $(38.3 \%)$. Adoption of digital technologies has been more prevalent among young people than adults, and this trend has been rising continuously. Ten- to 15-year-olds accounted for $54.5 \%$ of Internet users. Their primary reason for using the Internet was to play games $(65.4 \%)$, with more than half $(64.7 \%)$ reporting that they played games
Correspondence: Usaneya Perngparn College of Public Health Sciences, Chulalongkorn University, Institute Building 2-3, Soi Chulalongkorn 62, Phyathai Road, Pathumwan District, Bangkok 10330, Thailand

Tel +6622188159

Fax+6622552177

Email usaneya.p@chula.ac.th 
at Internet cafes. Most played games online (62.6\%) and nearly half reported that they played games at home $(46.6 \%)$. Almost all of them were using the Internet or computer at least 1-4 days a week (97\%). Six percent of Thai Internet users met the criteria for Internet addiction. The percentage of users who were addicted ranged from $6 \%$ to $15 \%$, accounting for three million people in 2012. In addition, it was estimated that one in eight children was addicted to gaming. ${ }^{2}$

In recent years, several studies have demonstrated that some gamers have trouble controlling how much time they spend playing games on a computer. ${ }^{3-5}$ Excessive use of online and video games has become a common habit that may result in adverse consequences. ${ }^{6}$ Although the positive effects of games and Internet use have a deep impact on human lives, especially their effect on education and learning, ${ }^{7}$ the possible negative effect of excessive gaming among children and adolescents has become the most concerning issue among psychologists, educators, parents, and researchers.

In Thailand, some studies on gaming addiction behavior attempted to develop interventions to solve gaming addiction among the youth. The National Institute on Drug Abuse ${ }^{8}$ reported that young children already face serious risk factors. If the intervention does not occur before adolescence, it is expected that there would be difficulties overcoming risks because adolescent attitudes and behaviors are well established and are not easily changed. Similarly, The Center of Game Addict Prevention at the Institute of Child and Adolescent, Ratchanakharin Mental Health, Department of Mental Health, Ministry of Public Health, Thailand, reported that the most significant factor leading to gaming addiction among children was caretakers' lack of knowledge and skill on the issue. This lack of knowledge can make children over seven times more likely to develop gaming addiction. ${ }^{2}$ Therefore, evidence-based approaches to gaming addiction among school-age children should guide interventions that involve parents and teachers to improve awareness of the harmful effects of gaming addiction.

Learning to actively control emotions and behaviors begins in early childhood. The process of self-regulation continues when they develop the ability to think about what they are doing and react accordingly. In contrast, children and adolescents with poor self-regulation skills face a greater risk of peer rejection, social problems, delinquency, and obesity. ${ }^{9}$ Young children need to develop self-regulation skills because of the strong influence these skills have on school readiness and building relationships with peers. ${ }^{10}$ Parents and teachers play a critical role as guides and models teaching children to control themselves.
Self-regulation remains, perhaps, even more important in the teen years, which are often marked by an increased vulnerability to risks such as truancy, ${ }^{11}$ peer victimization, and substance use. ${ }^{12}$ Adolescents who do not regulate their emotions and behavior are more likely to engage in risktaking and unhealthy behaviors. ${ }^{13}$ Being able to suppress impulsive behavior and to adjust behavior as appropriate has been linked to positive outcomes for children and adolescents. Self-regulation refers to both unconscious and conscious processes that affect the ability to control responses. ${ }^{14}$ It is a skill that has overarching effects on an individual's ability to tolerate unmet wants or needs, handle disappointments and failures, and work toward success. The ability to self-regulate is the foundation for compliance with accepted standards of conduct at home, school, and later, in the workplace. Selfregulation is often thought of as a dual process - cognitive and social-emotional. ${ }^{15,16}$ McClelland et al $^{17}$ believed that parents and teachers play a crucial role in the development of their children's self-regulation skills at home and in the classroom. These could be significant predictors of children's self-regulation skills that can provide organization, consistency, and structure. For example, by following the rules provided, children can have the chance to practice controlling their actions. The combination of family participation and school programs - or a multicomponent program - can be more effective than using a single program. ${ }^{8}$

Accordingly, a systematic review in the areas of prevention, treatment, and policy measures relating to problematic Internet and video game use policy actions was implemented. The result found that, in the Western world, all age groups are a target, and the review was less focused on adolescents as compared to those implemented in Asian countries. In Asian countries, there exists a tendency to think that adolescents can be cured even if they do not recognize the problem themselves and/or are resistant to changing their behavior. The South Korean model, in particular, is an exemplar of a coordinated response to a public health threat, with extensive government initiatives and long-term strategic plans at all three levels of prevention (i.e., universal, selective, and indicated). Western regions, by comparison, are dominated by prevention approaches led by nonprofit organizations and private enterprise. The future of prevention of gaming and Internet problems ultimately relies upon all stakeholders working collaboratively in the public interest, confronting the reality of the evidence base and developing practical, ethical, and sustainable countermeasures. ${ }^{18}$ The future of prevention of gaming and Internet problems ultimately relies upon all stakeholders working collaboratively in the public interest, 
confronting the reality of the evidence base and developing practical, ethical, and sustainable countermeasures. ${ }^{19}$ The reason for this may lie in the fact that the policies that have been outlined only addressed or influenced specific aspects of the problem instead of using a more integrative approach.

Presently, there are limitations to the universal preventive intervention program geared toward gaming addiction among primary schools. This age group cannot be overlooked as it poses additional challenges due to its vulnerability and need to protect the children's rights. This participatory-learning program sought to create a partnership between schools and families to foster sustainable intervention. Kumpfer and Alvarado $^{20}$ stated that parents were the most powerful factors involved in reducing negative behaviors among school-age children. Therefore, this study aimed to assess the effectiveness of the Participatory Learning School and Family Based Intervention Program for Preventing Game Addiction by Developing Self-Regulation of gaming addiction among students of grades 4 and 5 in Bangkok.

\section{Subjects and methods}

A quasi-experimental study was undertaken at primary schools in Bangkok, Thailand, between February and July 2015. The intervention group was imparted participatory learning in a school- and family-based intervention program for developing self-regulation skills against gaming addiction. The control group did not receive any intervention. The assessment was conducted at baseline, immediately post-intervention, and 3 months after completing the intervention. The study was ethically approved by the Ethics Review Committee for Research Involving Human Research Subjects, Chulalongkorn University. The certificate of approval number is COA No. 008/2558.

\section{Study population}

The participants in this study were students of grades 4 and 5 in Bangkok, Thailand. This study used G-Power version 3.1.5 (http://www.gpower.hhu.de/en.html), calculated by requisite power $=80 \%$ and alpha $=0.05$, with effect size $f=0.1$. The total sample size comprised 270 students, after adding $10 \%$ for dropouts and increasing the sample size to account for type II error.

The participating schools were recruited through multistage random sampling. Two comparable schools were randomly assigned as either experimental or control groups. The classrooms were also randomly selected, and all students in these selected classrooms were recruited - of the 310 cases, 151 students were in the intervention group and 159 in the control group, based on sample size calculation (Figure 1).
The students were recruited according to pre-specified inclusion and exclusion criteria. Inclusion criteria specified that students of grades 4 and 5 in primary schools under the jurisdiction of the Bangkok Primary Education Service Area, Thailand, willing to participate in this study, and whose parents signed the informed consent form were eligible for this study. Exclusion criteria were withdrawal from the study for any reason, failure to participate in the program for more than 2 weeks, and suffering from any condition that impaired communication, such as physical illness.

\section{Research instruments}

Self-administered questionnaires were adopted from the literature review and related studies in both Thai and English. The content captured in different sections of the questionnaires are described further.

\section{Part I: Student characteristics}

The questionnaires included both closed and open-ended questions addressing 12 items on the sociodemographic characteristics of the participants, including age, gender, grade point average (GPA), and level of education as well as characteristics of their parents, such as parenting style and family relationship.

\section{Part II: Games}

Knowledge about gaming and the problems of gaming addiction

This part of the evaluation comprised eight multiple-choice questions. This was modified from "Knowledge of computer games and the problem kids are addicted to the game today" questionnaire by Kajonboon. ${ }^{21}$ After testing the set of questions on 30 students at another school with similar characteristics to the sample population, the reliability coefficient was calculated by using the split-half method. The reliability coefficient was 0.708 and the index of consistency (IOC) from three experts was 0.92 . The correct answer for each question received one point, and the total possible score was eight.

Attitude toward gaming and the effects of game addiction This part of the assessment measured "attitude towards gaming" and was developed by Phosuwan. ${ }^{22}$ The reliability coefficient was tested, and the Cronbach's alpha coefficient was 0.749 . The total possible score of the eight items in this section varied from 8 to 40 points. A higher score indicated a better attitude of the student toward gaming and gaming addiction. 


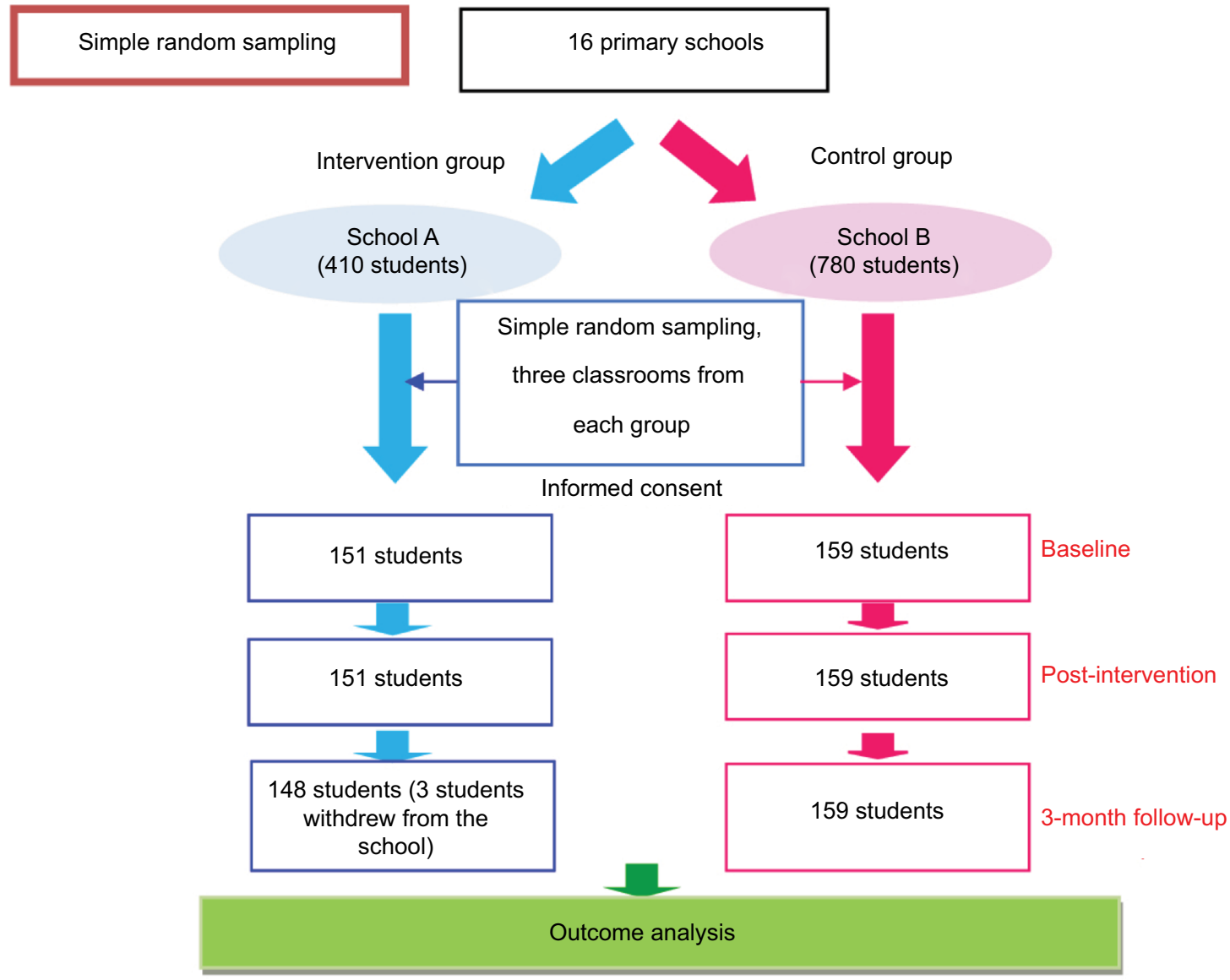

Figure I Study population at baseline, post-intervention, and 3 months follow-up.

\section{Pattern of gaming}

These questionnaires covered eight items through closed and open-ended questions about accessibility of games and gaming devices in participants' homes as well as the time and frequency at which games were played.

\section{Gaming addiction behavior}

This part used the standard tool known as the Game Addiction Screening Test (GAST) developed by Pornnoppadol et al. ${ }^{23}$ Cronbach's alpha of child and adolescent GAST was 0.92 , and the intra-class correlation coefficient was 0.90 . For males, the cutoff point for classified gaming addiction was 24 or greater and 16 or greater for females. High scores meant students were more addicted to games. ${ }^{23}$ This tool has 16 items. Each item had a 4-point rating scale from "not at all" to "yes" (0-3 points). Total scores varied from 0 to 48 points.

\section{Self-regulation}

Self-regulation was measured as the ability to control gaming addiction behaviors in children and adolescents by using the
Game Addiction Protection Scale (GAPS) developed by Pornnoppadol et al. ${ }^{24}$ These questionnaires consisted of 30 items with a reliability of 0.78 . Each item has a 4-point rating scale, from "not at all" or "never do" to "yes". With 30 items, the score could range from 0 to 90 points. Respondents were divided into two groups by a cutoff point: 0-64 represented low selfregulation, and 65 and greater represented high self-regulation. ${ }^{24}$

\section{Tools for parents}

To ensure the reliability of the children's answers, the researcher monitored the effect of the program through a weekly checklist. Parents were told to supervise their child in the practice of gaming addiction behavior and self-regulation, and to provide feedback to teachers each week.

\section{Interventional procedures}

The study consisted of a Participatory Learning School and Family Based Intervention Program for Preventing Game Addiction by Developing Self-Regulation skills on gaming addiction among students of grades 4 and 5. This program was developed based on self-regulation theory and used 
participatory learning by creating a partnership between school and family to develop a prevention program. The theory supporting this program was self-regulation (SR), developed by Bandura. ${ }^{25}$ Self-regulation is part of the social-cognitive theory group, which involves three stages comprising self-monitoring, self-evaluation, and self-reinforcement. The four components of self-regulation comprise standards, monitoring, strength, and motivation. ${ }^{26}$ Self-regulation is an important personality process by which people seek to exert control over their thoughts, feelings, impulses, appetites, and task performances. ${ }^{27}$ An important process of self-regulation is monitoring information about one's existing state and comparing it with the desired goal. ${ }^{28}$ This program does not change gaming addiction behavior directly; however, it can instead enhance self-regulation to promote confidence in refusing game playing, gain more knowledge about gaming addiction and its effects, as well as provide information about how to regulate themselves, the types of games they can play, suitable duration to play games, etc. All of these would help students prevent gaming addiction behavior.

The program required the involvement of teachers, to lead activities, and of parents, to help maintain consistency, during the program. "Master teachers", who underwent necessary training, took a leading role. They were the key actors educating the students and regulating gaming behavior. Families played a crucial role in maintaining program consistency. This program aimed to address knowledge, attitude, and self-regulation skills with regard to the ability to control and manage frequency of play and time spent gaming. The intervention contained 1 hour of activities a week during classes from weeks 1 to 8 (Table 1 ).

\section{Data analysis}

Descriptive statistics, chi-square test, and independent $t$-test were used to identify the significant differences between the intervention and control groups on the general characteristics of students at baseline measurement. Repeated measures ANOVA was used to test the effects of the interventional program. We considered 95\% confidence intervals (CIs) and $P$-value less than 0.05 of all analysis as indicative of statistical significance.

\section{Results}

\section{Baseline characteristics}

Similarities were observed between the intervention and control school groups. Of the 310 students who enrolled at baseline, $307(99.03 \%)$ were available for a follow-up of 3 months after the program. The three students who were unavailable were in the control group and had left school. Characteristics of the 310 students were collected at baseline in January 2015. Tables 2 and
3 show that baseline comparison of the general characteristics of students and their parents showed no statistically significant differences between the intervention and control groups.

However, only one variable - GPA - was significantly different between the two groups (Table 2). Students in the control-group school had a significantly higher GPA than those in the intervention school. In order to prevent GPA from affecting the findings of the study, the GPA was adjusted by using a covariate in repeated measures ANOVA when testing the effect of the intervention program.

\section{Pattern of game playing}

Of the 310 student participants, most (98.7\% in the intervention group and $97.5 \%$ in the control group) played games. Moreover, there were no statistically significant differences in gaming behavior between the intervention and the control groups $(P=0.447, P=0.064, P=0.585, P=0.203$, and $P=0.296$, respectively) as shown in Tables 4 and 5 .

\section{Effectiveness of the participatory-learning and family-based intervention program on developing self-regulation toward gaming addiction on changes over time between and within groups}

After adjusting for GPA at post-intervention and at the 3-month follow-up, repeated measures ANOVA was used to analyze the effectiveness of the intervention program. There was a statistically significant difference between the intervention and control groups $(P<0.001)$. Between subjects, there was no statistically significant difference. However, within-subject testing showed that the participatory-learning and family-based intervention program resulted in changes to mean knowledge, attitude, GAST, and GAPS scores over the three time points, with statistical significance as shown in Table 6. The trends of GAST scores clearly showed that there was a significant difference between both groups from the post-intervention assessment and the 3-month follow-up as presented in Figure 2, and this was similar to the trends of GAPS scores presented in Figure 3.

\section{Difference of knowledge, attitude, GAST, and GAPS score between the two groups at baseline, post-intervention, and at \\ 3-month follow-up}

There were statistically significant differences between the intervention and control groups in gaming knowledge at the post-intervention assessment and the 3-month follow-up 
Table I Overview of the "Participatory Learning School and Family Based Intervention Program for Preventing Game Addiction by Developing Self-Regulation" modules and instructional activities

\begin{tabular}{|c|c|c|c|}
\hline $\begin{array}{l}\text { Instructional } \\
\text { modules }\end{array}$ & Purpose & Core content & Activities/evaluation \\
\hline $\begin{array}{l}\text { Introduction } \\
\text { (week I) }\end{array}$ & $\begin{array}{l}\text { - To introduce an overview } \\
\text { of the program } \\
\text { - To gain knowledge about } \\
\text { gaming, type of game, } \\
\text { consequence of gaming, } \\
\text { and gaming addiction } \\
\text { behavior } \\
\text { - To investigate problem } \\
\text { situations for gaming } \\
\text { addiction in schools }\end{array}$ & $\begin{array}{l}\text { I. What is gaming? } \\
\text { 2. Type of game } \\
\text { 3. Rating games and their symbolism in } \\
\text { Thailand } \\
\text { 4. Consequence of gaming } \\
\text { 5. Gaming addiction behavior } \\
\text { 6. How to play games while avoiding } \\
\text { addiction to gaming? } \\
\text { 7. Time limit for playing games per day } \\
\text { 8. Education on the healthy gamer }\end{array}$ & $\begin{array}{l}\text { Activities: } \\
\text { - Ice-breaking, introduction, test for } \\
\text { baseline, VDO, group discussion } \\
\text { - Walk rally } \\
\text { Evaluation: } \\
\text { - Question and answer, pre-test } \\
\text { - Participation in classroom }\end{array}$ \\
\hline $\begin{array}{l}\text { Self-regulation } \\
\text { (week 2) }\end{array}$ & $\begin{array}{l}\text { - To gain knowledge about } \\
\text { self-regulation }\end{array}$ & $\begin{array}{l}\text { I. What is self-regulation? } \\
\text { 2. Why self-regulation is necessary? } \\
\text { 3. How can we develop self-regulation by } \\
\text { ourselves? }\end{array}$ & $\begin{array}{l}\text { Activities: } \\
\text { - Build rapport and provide description of } \\
\text { self-regulation } \\
\text { - VDO, group discussion } \\
\text { Evaluation: } \\
\text { - Question and answer } \\
\text { - Participation in classroom }\end{array}$ \\
\hline $\begin{array}{l}\text { Self-determined, } \\
\text { goal and standard } \\
\text { (week 3) }\end{array}$ & $\begin{array}{l}\text { - Students determine } \\
\text { goals to be achieved and } \\
\text { standards for behavior } \\
\text { - Goal setting and target } \\
\text { behavior }\end{array}$ & $\begin{array}{l}\text { I. How to assess yourself? } \\
\text { 2. Component of successful test } \\
\text { performance } \\
\text { 3. How to set goals in the short and long } \\
\text { term? } \\
\text { 4. Value of goal setting }\end{array}$ & $\begin{array}{l}\text { Activities: } \\
\text { - Test: are you addicted to gaming? } \\
\text { - Students analyze themselves } \\
\text { - Present result of self-assessment in group } \\
\text { - Goal setting by groups process } \\
\text { - Group presentation in class } \\
\text { Evaluation: } \\
\text { - Question and answer } \\
\text { - Result of self-assessment and goal setting } \\
\text { - Participation in classroom }\end{array}$ \\
\hline $\begin{array}{l}\text { Strategic planning } \\
\text { (week 4) }\end{array}$ & $\begin{array}{l}\text { - Searching for options and } \\
\text { formulating a plan }\end{array}$ & $\begin{array}{l}\text { - What is the option of planning? } \\
\text { - How to formulate a plan? } \\
\text { - How to search strategically to achieve } \\
\text { their plan? }\end{array}$ & $\begin{array}{l}\text { Activities: } \\
\text { - Brainstorming - group discussion } \\
\text { - Group presentation in class } \\
\text { Evaluation: } \\
\text { - Question and answer } \\
\text { - Participation in classroom }\end{array}$ \\
\hline $\begin{array}{l}\text { Self-monitoring } \\
\text { (week 5) }\end{array}$ & $\begin{array}{l}\text { - Self-monitoring: students } \\
\text { observe and monitor their } \\
\text { own performance }\end{array}$ & $\begin{array}{l}\text { - How to systemically develop strategic } \\
\text { plans for attempting their own goals? } \\
\text { - Provide a model guideline to attempt } \\
\text { their goals } \\
\text { - Option of self-monitoring }\end{array}$ & $\begin{array}{l}\text { Activities: } \\
\text { - Teach students about systemically } \\
\text { developing strategic plans for attempting } \\
\text { their goal } \\
\text { - Group discussion } \\
\text { - Group presentation in class } \\
\text { Evaluation: } \\
\text { - Question and answer } \\
\text { - Participation in classroom }\end{array}$ \\
\hline $\begin{array}{l}\text { Self-instructions } \\
\text { (week 6) }\end{array}$ & $\begin{array}{l}\text { - Self-instructions: students } \\
\text { give selves instructions } \\
\text { (either loudly or quietly) to } \\
\text { help guide actions }\end{array}$ & $\begin{array}{l}\text { - What is self-instruction? } \\
\text { - What are appropriate rewards and } \\
\text { punishment? }\end{array}$ & $\begin{array}{l}\text { Activities: } \\
\text { - Teach about self-instructions } \\
\text { - Brainstorming } \\
\text { - Group discussion } \\
\text { - Group presentation in class } \\
\text { Evaluation: } \\
\text { - Question and answer } \\
\text { - Participation in classroom }\end{array}$ \\
\hline
\end{tabular}


Table I (Continued)

\begin{tabular}{|c|c|c|c|}
\hline $\begin{array}{l}\text { Instructional } \\
\text { modules }\end{array}$ & Purpose & Core content & Activities/evaluation \\
\hline $\begin{array}{l}\text { Self-reflection } \\
\text { (week 7) }\end{array}$ & $\begin{array}{l}\text { - Students have to } \\
\text { implement the plan and } \\
\text { response }\end{array}$ & $\begin{array}{l}\text { - How to implement the plan and } \\
\text { response? }\end{array}$ & $\begin{array}{l}\text { Activities: } \\
\text { - Students share their experiences and } \\
\text { show how to achieve their goal? } \\
\text { - Group discussion } \\
\text { - Group presentation in class } \\
\text { Evaluation: } \\
\text { - Question and answer } \\
\text { - Participation in classroom }\end{array}$ \\
\hline $\begin{array}{l}\text { Self-imposed } \\
\text { contingencies } \\
\text { (week 8) }\end{array}$ & $\begin{array}{l}\text { - Self-imposed contingencies: } \\
\text { students impose their own } \\
\text { consequences for success } \\
\text { or failure }\end{array}$ & $\begin{array}{l}\text { - What is the benefit of self-regulation? } \\
\text { - Students response and feedback for their } \\
\text { own consequences for success or failure }\end{array}$ & $\begin{array}{l}\text { Activities: } \\
\text { - Students share their experiences } \\
\text { - Group presentation about their action } \\
\text { and evaluate plan in class } \\
\text { - Give rewards to all students enrolled in } \\
\text { this study } \\
\text { - Awarding certificates } \\
\text { Evaluation: } \\
\text { - Question and answer } \\
\text { - Participation in classroom }\end{array}$ \\
\hline
\end{tabular}

Note: Activities by Master teachers and RA.

Abbreviation: VDO, virtual data object; RA, research assistants.

Table 2 Baseline characteristics of students $(\mathrm{N}=310)$

\begin{tabular}{|c|c|c|c|}
\hline $\begin{array}{l}\text { Student } \\
\text { characteristics }\end{array}$ & $\begin{array}{l}\text { Intervention } \\
(n=15 \mathrm{I}) \\
\mathrm{n}(\%)\end{array}$ & $\begin{array}{l}\text { Control } \\
(n=159) \\
n(\%)\end{array}$ & $P$-value \\
\hline Gender & & & $0.073^{a}$ \\
\hline Boys & $73(48.3)$ & $93(58.5)$ & \\
\hline Girls & $78(51.7)$ & $66(4 \mid .5)$ & \\
\hline Age (years) & & & $0.196^{\mathrm{a}}$ \\
\hline 8 and 9 & $49(32.5)$ & $4 \mathrm{I}(25.8)$ & \\
\hline$\geq 10$ & $102(67.5)$ & I I 8 (74.2) & \\
\hline Mean (SD) & $9.77(0.79)$ & $10.05(0.67)$ & \\
\hline Median (IQR) & $10(1)$ & $10(2)$ & \\
\hline Min-max & $8-12$ & $8-12$ & \\
\hline Level of education & & & $0.634^{\mathrm{a}}$ \\
\hline Grade 4 & 81 (53.6) & 81 (50.9) & \\
\hline Grade 5 & $70(46.4)$ & $78(49.1)$ & \\
\hline \multicolumn{4}{|l|}{ Grade point average } \\
\hline Mean (SD) & $3.25(0.56)$ & $3.63(0.38)$ & $<0.00 \mathrm{I}^{\mathrm{b}}$ \\
\hline Median (IQR) & $3.31(0.85)$ & $3.76(0.50)$ & \\
\hline Min-max & $1.56-4.00$ & $2.45-4.00$ & \\
\hline
\end{tabular}

Notes: Significant at $P$-value $<0.05$. ${ }^{a}$ Chi-square test. bindependent $t$-test. Abbreviation: IQR, interquartile range.

$(P<0.001)$. Attitude toward games at the post-intervention assessment and the 3-month follow-up showed statistically significant differences between the intervention and the control groups $(P<0.001$ and $P=0.013$, respectively). The GAST scores at the post-intervention assessment and the 3-month follow-up also showed statistically significant differences between the intervention and the control groups $(P<0.001)$. GAPS scores at post-intervention and at the 3-month follow-up were also found to have statistically significant differences between the intervention and the control groups $(P<0.001)$ as seen in Table 7 .

\section{Effect of the program on improving gaming addiction behavior}

Practically, among the intervention group, the percentage of students who do not play games increased post-intervention, and had slightly decreased at the 3-month follow-up (1.3, 7.9, and $6.1 \%$, respectively; Table 8 ). Moreover, we found that gaming behavior in the intervention group had lower average days spent on gaming than in the control group. The average time expended playing games during weekdays among the intervention and the control groups were 0.91 and 1.08 hours/ day, respectively. On weekends, the average time spent on games were 1.73 and 1.93 hours/day in the intervention and control groups, respectively (Table 9). Moreover, in the 3-month followup, the researcher found that the intervention group still had a lower average number of days spent on gaming than the control group (3.57 and 4.03 days, respectively). The average time of playing games on weekdays among the intervention and the control groups were similar (1.21 and 1.41 hours, respectively). The intervention group spent lesser time per day on weekdays than the control group - at 2.15 and 2.44 hours - respectively. Nevertheless, there were statistically significant differences in the duration spent gaming between the intervention and the control groups in days per week ( $P=0.034$; Table 9$)$. 
Table 3 Baseline characteristics of parents $(\mathrm{N}=310)$

\begin{tabular}{|c|c|c|c|}
\hline \multirow[t]{2}{*}{ Parent characteristics } & \multirow{2}{*}{$\begin{array}{l}\text { Intervention } \\
(n=15 I) \\
n(\%)\end{array}$} & \multirow{2}{*}{$\begin{array}{l}\text { Control } \\
(n=159) \\
n(\%)\end{array}$} & \multirow[t]{2}{*}{$P$-value } \\
\hline & & & \\
\hline Parent's marital status & & & $0.062^{\mathrm{a}}$ \\
\hline Married & $134(88.7)$ & $129(8 \mid .1)$ & \\
\hline Widowed/separated/divorced/deceased & $17(11.3)$ & $30(18.9)$ & \\
\hline Living arrangement of child & & & $0.137^{\mathrm{a}}$ \\
\hline With parents, both father and mother & |3| (86.8) & $125(78.6)$ & \\
\hline With father or mother & $13(8.6)$ & $25(15.7)$ & \\
\hline With relatives or others & $7(4.6)$ & $9(5.7)$ & \\
\hline \multicolumn{4}{|l|}{ Father's education } \\
\hline Primary, secondary, and vocational school & $67(44.4)$ & $84(49.4)$ & $0.785^{\mathrm{a}}$ \\
\hline Bachelor's degree or higher & $73(54.9)$ & $86(50.6)$ & \\
\hline Mother's education & & & $0.072^{\mathrm{a}}$ \\
\hline Primary, secondary, and vocational school & $56(37.1)$ & $75(47.2)$ & \\
\hline Bachelor's degree or higher & 95 (62.9) & $84(52.8)$ & \\
\hline Father's occupation & & & $0.664^{\mathrm{a}}$ \\
\hline Government career & $56(37.1)$ & $51(32.1)$ & \\
\hline Farmer, trader, or other & $31(20.5)$ & $27(17.0)$ & \\
\hline Professional contractor & $15(9.9)$ & $20(12.6)$ & \\
\hline Employee of private company & $31(20.5)$ & $40(25.2)$ & \\
\hline Private owners & $18(11.9)$ & $21(13.2)$ & \\
\hline Mother's occupation & & & $0.322^{\mathrm{a}}$ \\
\hline Government career & $59(39.1)$ & $53(33.3)$ & \\
\hline Farmer, trader, or other & $38(45.8)$ & $45(28.3)$ & \\
\hline Professional contractor & II (7.3) & $5(3.1)$ & \\
\hline Employee of private company & $28(18.5)$ & $37(23.3)$ & \\
\hline Private owner & $15(9.9)$ & $19(11.9)$ & \\
\hline Family relationship & & & $0.918^{a}$ \\
\hline Good relationship & |4| (93.4) & I $48(93.1)$ & \\
\hline Conflict & $10(6.6)$ & II (6.9) & \\
\hline Parenting style & & & $0.093^{\mathrm{a}}$ \\
\hline Permissive & $47(29.6)$ & $4 \mid(27.2)$ & \\
\hline Authoritarian & $106(66.6)$ & $93(61.6)$ & \\
\hline Authoritative & $3(1.9)$ & $10(6.6)$ & \\
\hline Uninvolved & $3(1.9)$ & $7(4.6)$ & \\
\hline
\end{tabular}

Note: ${ }^{a}$ Chi-square.

\section{Discussion}

\section{Effectiveness of the intervention program on increasing knowledge}

Results showed that the Participatory Learning School and Family Based Intervention Program for Preventing Game Addiction by Developing Self-Regulation toward gaming addiction was effective in increasing knowledge about gaming and its effects. Findings were related to those reported by Kajonboon ${ }^{21}$; her study revealed that knowledge of computer games was significantly higher after students completed the program. Meanwhile, the findings of Ferland et $\mathrm{al}^{29}$ indicated that knowledge about gaming significantly improved subjects' knowledge. Furthermore, Williams et al ${ }^{30}$ used school-based prevention programs to solve a gambling problem among students of grades 9-12 at 4 months after receiving the program; students in the intervention group had significantly improved knowledge about gambling and demonstrated decreased gambling frequency.

\section{Effectiveness of the intervention program in improving attitudes toward gaming and its effect}

Results confirmed that the intervention program successfully improved attitudes toward gaming and its effects. Seenuan et $a l^{31}$ had pointed out that the mean score for attitude was significantly higher in the comparison group after completion of the family task program with participatory-learning methods for preventing computer gaming addiction among school-age children. Furthermore, Williams et a ${ }^{30}$ also found that students in the intervention group had significantly more negative attitudes toward gambling following the use of 
Table 4 Baseline characteristics of participants' gaming behavior $(\mathrm{N}=310)$

\begin{tabular}{|c|c|c|c|}
\hline Variables & $\begin{array}{l}\text { Intervention } \\
(n=15 I)\end{array}$ & $\begin{array}{l}\text { Control } \\
(n=159)\end{array}$ & $P$-value \\
\hline & n (\%) & n (\%) & \\
\hline Play games & & & $0.447^{\mathrm{a}}$ \\
\hline No & $2(1.3)$ & $4(2.5)$ & \\
\hline Yes & $149(98.7)$ & $155(97.5)$ & \\
\hline Have devices at home & & & $0.064^{\mathrm{a}}$ \\
\hline Yes & I 37 (90.7) & $153(96.2)$ & \\
\hline No & $14(9.3)$ & $6(3.8)$ & \\
\hline Area allowed to use & & & $0.585^{a}$ \\
\hline \multicolumn{4}{|l|}{ devices at home } \\
\hline Living room & $73(53.1)$ & $95(62.1)$ & \\
\hline Work room & $23(16.8)$ & $23(15.0)$ & \\
\hline Bedroom & $22(16.2)$ & $16(10.5)$ & \\
\hline Everywhere & $19(13.9)$ & $19(12.4)$ & \\
\hline Internet access at home & & & $0.203^{\mathrm{a}}$ \\
\hline Yes & $122(89.1)$ & $146(94.3)$ & \\
\hline No & $15(9.9)$ & $7(5.7)$ & \\
\hline
\end{tabular}

Notes: Significant at $P$-value $<0.05$. ${ }^{a}$ Chi-square test.

Table 5 Baseline characteristics of participant gaming behavior among students who played games $(\mathrm{N}=304)$

\begin{tabular}{|c|c|c|c|}
\hline \multirow[t]{2}{*}{ Variables } & \multirow{2}{*}{$\begin{array}{l}\text { Intervention } \\
(\mathrm{n}=\mathrm{I49)} \\
\mathrm{n}(\%)\end{array}$} & \multirow{2}{*}{$\begin{array}{l}\text { Control } \\
(n=I 55) \\
n(\%)\end{array}$} & \multirow[t]{2}{*}{$P$-value } \\
\hline & & & \\
\hline \multicolumn{4}{|l|}{ Type of game usually played } \\
\hline Games online & $80(53.7)$ & $96(61.9)$ & $0.296^{\mathrm{a}}$ \\
\hline Games offline & $26(17.4)$ & $19(12.3)$ & \\
\hline Both online and offline & $43(28.9)$ & $40(25.8)$ & \\
\hline \multicolumn{4}{|c|}{ Place where games are played } \\
\hline At home & $143(96.0)$ & $155(100.0)$ & \\
\hline $\begin{array}{l}\text { Outside the home (such as } \\
\text { internet cafe, department } \\
\text { stores, and school) }\end{array}$ & $6(4.0)$ & $0(0)$ & \\
\hline \multicolumn{4}{|c|}{ Type of games played (ranks I-3) } \\
\hline \multicolumn{4}{|c|}{ Intervention group } \\
\hline I. Line games & $35(23.2)$ & & \\
\hline 2. Fighting games & $24(15.9)$ & & \\
\hline 3. Adventure games & $20(13.2)$ & & \\
\hline \multicolumn{4}{|l|}{ Control group } \\
\hline I. Line games & & $74(46.5)$ & \\
\hline 2. Shooting games & & $17(10.7)$ & \\
\hline 3. Adventure games & & $13(8.2)$ & \\
\hline
\end{tabular}

Notes: Significant at $P$-value $<0.05$. ${ }^{a}$ Chi-square test.

school-based prevention programs to solve gambling problems among students of grades 9-12. Moreover, the program brought about a statistically significant decrease in gambling frequency and rates of gambling problems.

\section{Effectiveness of the intervention program in improving gaming addiction behavior}

Although results from this study found that GAST scores at post-intervention in the intervention group radically decreased from baseline scores and slightly increased at the 3-month follow-up, this was consistent with the results of Joo and Park $^{32}$ who studied the effect of empowerment education programs on Internet gaming addiction among middle school students. Their results indicated that the experimental group had lower Internet game addiction scores than the control group. However, the trends clearly showed that there was a significant difference between GAST scores for both groups from post-intervention to the 3-month follow-up. GAST scores may have increased at the 3-month follow-up because of the time period in the study. The intervention program was completed in March 2015, after which schools went on a 3-month break in summer. Students might have had more free time to play games than during the school term. Kolkijkovin et $\mathrm{a}^{33}$ found that the risk factors of gaming addiction included the frequency and length of time spent playing games. Nevertheless, after-school activities other than gaming helped improve child temperament and were, thus, protective factors. Therefore, teaching self-discipline in terms of self-regulation with regard to time used in to play games could solve and prevent gaming addiction among school-age children.

\section{Effectiveness of the intervention program on increasing self-regulation on gaming addiction}

The outcome of this study concurs with that of the study of Thongkambunjong et al, ${ }^{34}$ who found that online gaming addiction behavior was negatively affected by self-control. A longitudinal study by Seay and Kraut ${ }^{35}$ revealed that the player's reasons for playing influenced the development of problematic usage. These effects were overshadowed by the central importance of self-regulation in managing both timing and amount of playing. An individual's level of selfregulatory activity was shown to be very important in allowing them to avoid negative outcomes including problematic use. Billieux and Van der Linden ${ }^{36}$ suggested that poor selfregulation capacities have been shown to play a critical role in problematic Internet use.

Self-regulation was an important factor toward gaming behavior in this study. The finding of the participatorylearning and family-based intervention program may be taken to suggest the importance of raising self-regulation with a small effect size of $0.254 .{ }^{37}$ Similarly, in the study of Mun and Lee ${ }^{38}$ who used interventions for empowerment and methods of behavioral modification and test its effects on the self-regulation and internet addiction, the effect size was 0.269 . Whereas participants of their study were 28 persons 
Table 6 Repeated measures ANOVA of knowledge, attitude toward gaming and its effect, GAST scores, and GAPS scores between the intervention and control groups $(\mathrm{N}=307)$

\begin{tabular}{|c|c|c|c|c|c|}
\hline Variables & SS & $d f$ & MS & F-test & $P$-value \\
\hline \multicolumn{6}{|l|}{ Knowledge } \\
\hline \multicolumn{6}{|l|}{ Between subjects } \\
\hline Intervention & 324.674 & I & 324.674 & 102.720 & $<0.001$ \\
\hline Error (between-group error) & 960.868 & 304 & 3.161 & & \\
\hline \multicolumn{6}{|l|}{ Within subjects } \\
\hline Time & 4.508 & 1.950 & 2.312 & 1.428 & 0.241 \\
\hline Intervention $\times$ time & 47.042 & 1.950 & 24.123 & 14.897 & $<0.001$ \\
\hline Error (within-group error) & 959.977 & 592.831 & 1.619 & & \\
\hline \multicolumn{6}{|l|}{ Attitude } \\
\hline \multicolumn{6}{|l|}{ Between subjects } \\
\hline Intervention & 9461.265 & I & 9461.265 & 220.667 & $<0.001$ \\
\hline Error (between-group error) & 13034.246 & 304 & 42.876 & & \\
\hline \multicolumn{6}{|l|}{ Within subjects } \\
\hline Time & 57.545 & 1.823 & 31.562 & 1.509 & 0.223 \\
\hline Intervention $\times$ time & 297.134 & 1.823 & 162.973 & 7.792 & 0.001 \\
\hline Error (within-group error) & 11593.120 & 554.256 & 20.917 & & \\
\hline \multicolumn{6}{|l|}{ GAST scores } \\
\hline \multicolumn{6}{|l|}{ Between subjects } \\
\hline Intervention & 9461.265 & 1 & 9461.265 & 220.667 & $<0.001$ \\
\hline Error (between-group error) & 13034.246 & 304 & 42.876 & & \\
\hline \multicolumn{6}{|l|}{ Within subjects } \\
\hline Time & 57.545 & 1.823 & 31.562 & 1.509 & s0.223 \\
\hline Intervention $\times$ time & 297.134 & 1.823 & 162.973 & 7.792 & 0.001 \\
\hline Error (within-group error) & 11593.120 & 554.256 & 20.917 & & \\
\hline \multicolumn{6}{|l|}{ GAPS scores } \\
\hline \multicolumn{6}{|l|}{ Between subjects } \\
\hline Intervention & 43152.820 & 1 & 43152.820 & 223.271 & $<0.001$ \\
\hline Error (between-group error) & 58755.802 & 304 & 193.276 & & \\
\hline \multicolumn{6}{|l|}{ Within subjects } \\
\hline Time & 101.718 & 2 & 50.859 & 0.430 & 0.649 \\
\hline Intervention $\times$ time & 1871.226 & 2 & 935.613 & 7.914 & $<0.001$ \\
\hline Error (within-group error) & 71875.144 & 608 & 118.216 & & \\
\hline
\end{tabular}

Note: Bold values are significant at $p<0.001$.

Abbreviations: GAST, Game Addiction Screening Test; GAPS, Game Addiction Protection Scale; SS, sum of squares; df, degrees of freedom; MS, mean squares.

Table 7 Pairwise comparisons of the different measurements of knowledge, attitude, GAST, and GAPS scores between the intervention group $(n=148)$ and control group $(n=159)$

\begin{tabular}{|c|c|c|c|c|c|c|c|}
\hline \multirow[t]{2}{*}{ Time } & \multicolumn{2}{|l|}{ Group } & \multirow{2}{*}{$\begin{array}{l}\text { Mean } \\
\text { difference } \\
\mathbf{i}-\mathbf{j}\end{array}$} & \multirow[t]{2}{*}{ SE } & \multirow[t]{2}{*}{$P$-value } & \multicolumn{2}{|c|}{$\begin{array}{l}95 \% \text { confidence interva } \\
\text { for difference }{ }^{a}\end{array}$} \\
\hline & $\mathbf{i}$ & j & & & & Lower & Upper \\
\hline \multicolumn{8}{|l|}{ Knowledge } \\
\hline Baseline & Intervention & Control & $0.425 *$ & 0.197 & 0.032 & 0.038 & 0.811 \\
\hline Post-intervention & Intervention & Control & $0.745^{*}$ & 0.159 & $<0.001$ & 0.432 & 1.058 \\
\hline 3 months & Intervention & Control & $1.576 *$ & 0.176 & $<0.001$ & 1.230 & 1.923 \\
\hline \multicolumn{8}{|l|}{ Attitude } \\
\hline Baseline & Intervention & Control & -0.390 & 0.643 & 0.544 & -1.655 & 0.874 \\
\hline Post-intervention & Intervention & Control & $2.507^{*}$ & 0.584 & $<0.001$ & 1.358 & 3.656 \\
\hline 3 months & Intervention & Control & $1.692 *$ & 0.681 & 0.013 & 0.353 & 3.032 \\
\hline \multicolumn{8}{|l|}{ GAST } \\
\hline Baseline & Intervention & Control & 1.462 & 1.282 & 0.255 & $-1.06 \mid$ & 3.984 \\
\hline Post-intervention & Intervention & Control & $-7.758^{*}$ & 1.127 & $<0.001$ & -9.975 & $-5.54 \mid$ \\
\hline 3 months & Intervention & Control & $-9.090 *$ & I.I48 & $<0.001$ & -11.349 & -6.830 \\
\hline \multicolumn{8}{|l|}{ GAPS } \\
\hline Baseline & Intervention & Control & 1.462 & 1.282 & 0.255 & $-1.06 \mid$ & 3.984 \\
\hline Post-intervention & Intervention & Control & $-7.758^{*}$ & I. 127 & $<0.001$ & -9.975 & $-5.54 \mid$ \\
\hline 3 months & Intervention & Control & $-9.090 *$ & 1.148 & $<0.001$ & -11.349 & -6.830 \\
\hline
\end{tabular}

Notes: Based on estimated marginal means. ${ }^{*}$ The mean difference is significant at the 0.05 level. ${ }^{~}$ Adjustment for multiple comparisons: Bonferroni. Bold values are significant at $p<0.001$.

Abbreviations: GAST, Game Addiction Screening Test; GAPS, Game Addiction Protection Scale; SE, standard error. 
Table 8 Differences among students who played games and did not play games among the intervention and the control groups at baseline, post-intervention, and the 3-month follow-up

\begin{tabular}{|c|c|c|c|c|c|}
\hline \multirow[t]{2}{*}{ Time } & \multicolumn{2}{|c|}{ Intervention, $\mathbf{n}(\%)$} & \multicolumn{2}{|c|}{ Control, n (\%) } & \multirow[t]{2}{*}{$P$-value } \\
\hline & $\begin{array}{l}\text { Played } \\
\text { games }\end{array}$ & $\begin{array}{l}\text { Did not } \\
\text { play games }\end{array}$ & $\begin{array}{l}\text { Played } \\
\text { games }\end{array}$ & $\begin{array}{l}\text { Did not } \\
\text { play games }\end{array}$ & \\
\hline Baseline $(n=15 \mid, n=159)$ & $149(98.7)$ & $2(1.3)$ & $155(97.5)$ & $4(2.5)$ & 0.685 \\
\hline Post-intervention $(n=151, n=159)$ & $139(92.1)$ & $12(7.9)$ & 157 (98.7) & $2(1.3)$ & $0.005^{*}$ \\
\hline 3-month follow-up ( $n=148 * *, n=159)$ & $139(93.9)$ & $9(6.1)$ & $157(98.7)$ & $2(1.3)$ & $0.030 *$ \\
\hline
\end{tabular}

Notes: *Significant at $P$-value $<0.05$. **Dropout, three cases. Analysis by Fisher's exact test.

Table 9 Comparison of frequency and amount of time spent on gaming at post-intervention and 3-month follow-up between the intervention group and the control group $(n=307)$

\begin{tabular}{|c|c|c|c|c|}
\hline \multirow[t]{2}{*}{ Variables } & \multicolumn{2}{|c|}{ Intervention $(n=148)$} & \multicolumn{2}{|l|}{ Control $(n=159)$} \\
\hline & Post-intervention & 3-month follow-up & Post-intervention & 3-month follow-up \\
\hline \multicolumn{5}{|c|}{ Frequency of days used to play games } \\
\hline \multicolumn{5}{|l|}{ per week } \\
\hline Mean \pm SD & $2.83 \pm 1.123 * *$ & $3.57 \pm 1.674^{*}$ & $3.44 \pm 1.644$ & $4.03 \pm 2.048$ \\
\hline Median (IQR) & $3.00(1)$ & $3.00(3)$ & $3.00(3)$ & $3.00(5)$ \\
\hline Min-max & $0-7$ & $0-7$ & $1-7$ & $\mathrm{I}-7$ \\
\hline \multicolumn{5}{|c|}{ Gaming time on weekdays } \\
\hline \multicolumn{5}{|c|}{ (Monday-Friday) (hours/day) } \\
\hline Mean \pm SD & $0.91 \pm 0.698^{*}$ & $1.21 \pm 0.808$ & $1.08 \pm 0.732$ & $\mid .4 I \pm I .05 I$ \\
\hline Median (IQR) & $1.00(0.50)$ & $1.00(1.00)$ & $1.00(1.00)$ & $1.00(1.50)$ \\
\hline Min-max & $0-5$ & $0-4$ & $0-4$ & $0-6$ \\
\hline \multicolumn{5}{|c|}{$\begin{array}{l}\text { Gaming time on weekends (Saturday } \\
\text { and Sunday) (hours/day) }\end{array}$} \\
\hline Mean \pm SD & $1.73 \pm 1.25 \mid$ & $2.15 \pm 1.359$ & $1.97 \pm 1.193$ & $2.44 \pm 1.690$ \\
\hline Median (IQR) & $1.50(1)$ & $2.00(2)$ & $2.00(2)$ & $2.00(2)$ \\
\hline Min-max & $0-7.50$ & $0-7$ & $0-5$ & $0-10$ \\
\hline
\end{tabular}

Notes: ${ }^{*}$ Significant at $P$-value $<0.05$. **Significant at $P$-value $<0.001$. Dropout, three cases.

Abbreviation: IQR, interquartile range.

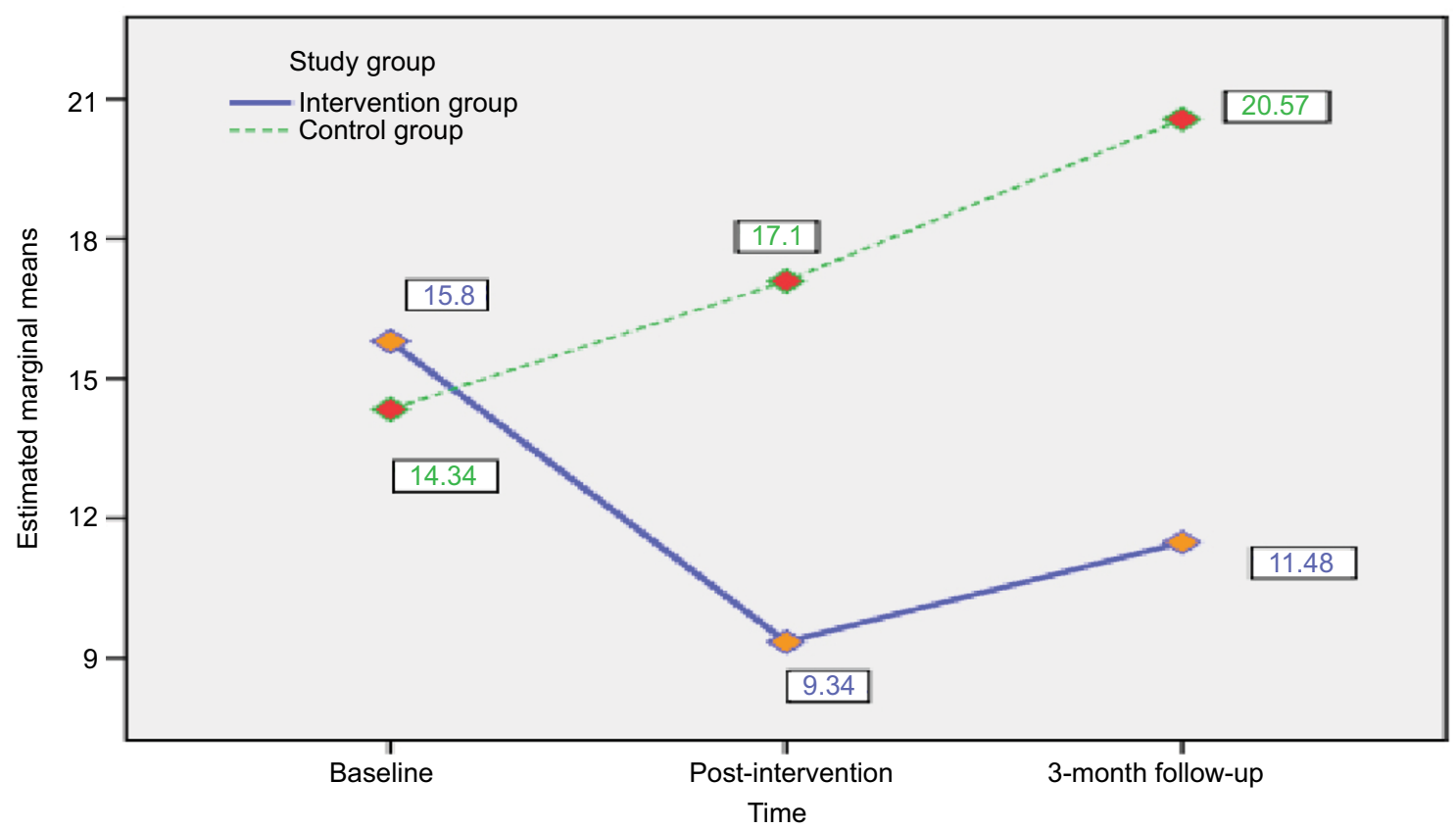

Figure 2 Changes over time of GAST scores between the intervention group and control group. Abbreviation: GAST, Game Addiction Screening Test. 


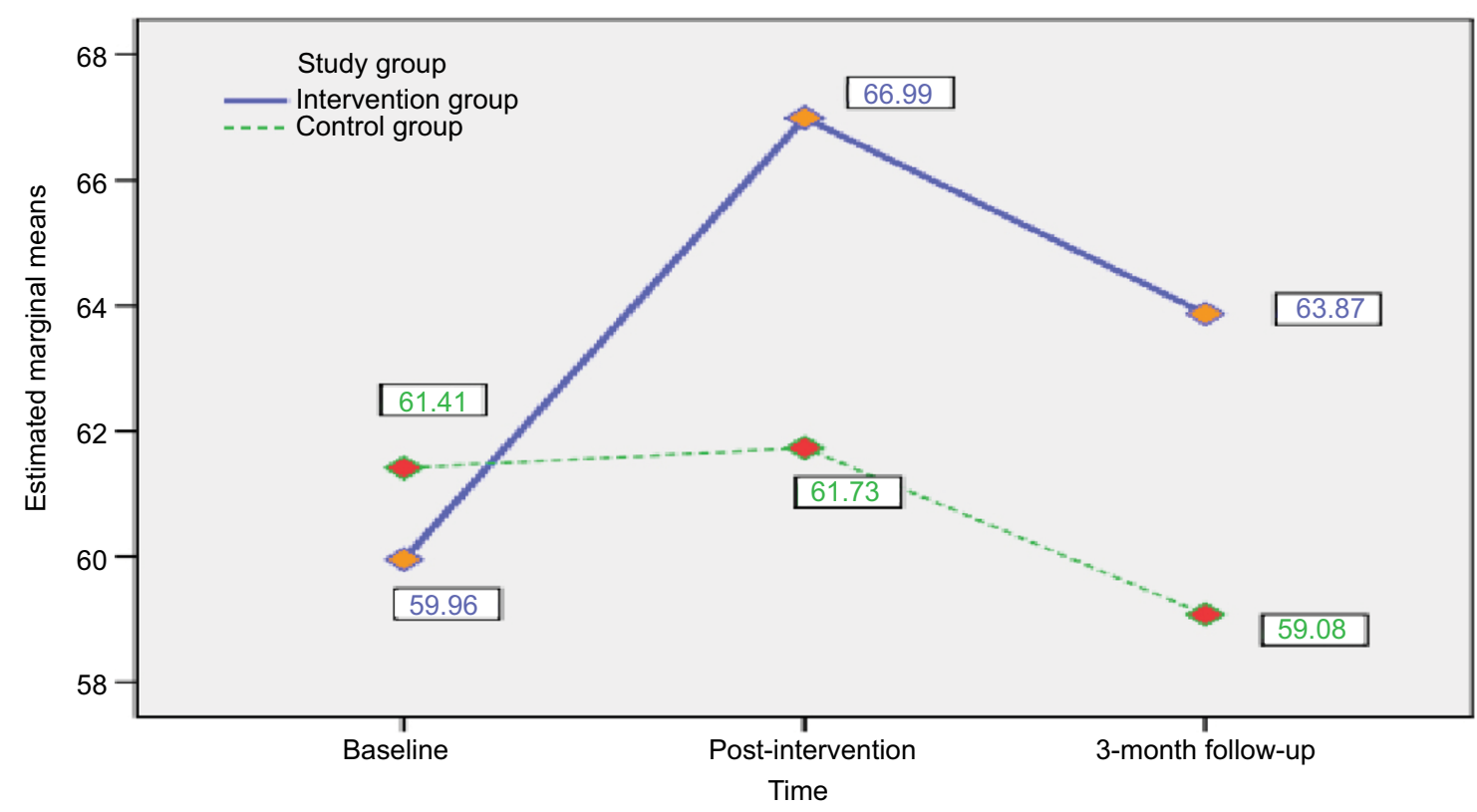

Figure 3 Change over time of GAPS scores between the intervention group and control group. Abbreviation: GAPS, Game Addiction Protection Scale.

per group, the participants in this study were classified as 151 and 155 persons per group.

\section{Strengths}

The strengths of this study include a focus on younger youths who tend toward becoming addicted to gaming. There is a gap in the age group of participants; in this vulnerable group, is difficult to conduct research on data and protect their rights.

\section{Limitations of the study}

This study should be considered in light of its limitations. First, the study was carried out in only two primary schools in Bangkok, which are located in an urban area, being the capital city of Thailand. The study findings may not be representative of the other areas. Second, due to a limitation of time, this study lacked a long-term follow-up. Finally, the use of a weekly checklist from participant's parents to monitor changes could cause measurement error due to over- or under-reporting recall bias or social desirability bias.

\section{Conclusion}

The participatory-learning and family-based intervention program was effective in developing self-regulation toward gaming addiction in terms of improving knowledge and attitude about game and its effects and self-regulation on gaming addiction. In addition, it can show improvements in gaming addiction behavior over time. Research suggests that the intervention program should be considered to be an appropriate intervention strategy to prevent and improve gaming addiction behavior among primary school students.

\section{Acknowledgments}

The study was supported by The 90th Anniversary of Chulalongkorn University Fund (Rachadaphiseksomphot Endowment Fund: GCUGR1125572049D). We would like to express our grateful acknowledgements to Associate Professor Chanvit Pornnoppadol from the Child and Adolescent Psychiatry Department of Psychiatry, Siriraj Hospital, for giving us the questionnaires used for assessments in this study. The authors also express their deepest gratitude to all participants for their contribution to the study.

\section{Disclosure}

The authors report no conflicts of interest in this work.

\section{References}

1. National Statistical Office. [Adolescents: Internet: online games]. 2013. Available from: http://service.nso.go.th/nso/nsopublish/citizen/news/ news_internet_teen.jsp. Accessed March 27, 2016. Thai.

2. Visanuyothin T. [Thai national health: Brainstroming to solve 2.5 million Thai youth addicted to the game]. 2012. Available from: www.hfocus. org/content/2013/110/5029. Accessed April 27, 2014. Thai.

3. Wan CS, Chiou WB. Why are adolescents addicted to online gaming? An interview study in Taiwan. Cyberpsychol Behav. 2006;9(6):762-766.

4. Hussain Z, Griffiths MD. Excessive use of massively multi-player online role-playing games: a pilot study. Int J Ment Health Addict. 2009;7(4): 563-571.

5. Smahel D, Blinka L, Ledabyl O. Playing MMORPGs: connections between addiction and identifying with a character. Cyberpsychol Behav. 2008;11(6):715-718. 
6. Bruner O, Bruner K. Playstation Nation: Protect Your Child from Video Game Addiction. New York, NY: Center Street Hachette Book Group; 2006.

7. Ghorbani NR, Heidari RN. Effects of information and communication technology on youth's health knowledge. Asia Pac J Public Health. 2011;23(3):363-368.

8. National Institute on Drug Abuse. Preventing Drug Use among Children and Adolescents: A Research-Based Guide for parents, Educators and Community Leaders. Bethesda, MD: NIH Publication; 2003.

9. Trentacosta CJ, Shaw DS. Emotional self-regulation, peer rejection, and antisocial behavior: developmental associations from early childhood to early adolescence. J Appl Dev Psychol. 2009;30(3):356-365.

10. Phillips DA, Shonkoff JP. From Neurons to Neighborhoods: The Science of Early Childhood Development. Washington, DC: National Academies Press; 2000.

11. McCluskey CP, Bynum TS, Patchin JW. Reducing chronic absenteeism: an assessment of an early truancy initiative. Crime Delinq. 2004;50(2):214-234

12. Wulfert E, Block JA, Santa Ana E, Rodriguez ML, Colsman M. Delay of gratification: impulsive choices and problem behaviors in early and late adolescence. J Pers. 2002;70(4):533-552.

13. Grolnick WS, Gurland ST, Jacob KF, Decourcey W. The development of self-determination in middle childhood and adolescence. In: Wigfield A, Eccles JS, editors. Development of Achievement Motivation. 1st ed. San Diego, CA: Academic Press; 2002:147-171.

14. Carver CS, Scheier MF. Self-regulation of action and affect. In: Vohs KD, Baumeister RF, editors. Handbook of Self-Regulation: Research, Theory, and Applications. 2nd ed. New York, NY: Guilford; 2004:13-39.

15. Blair C, Razza RP. Relating effortful control, executive function, and false belief understanding to emerging math and literacy ability in kindergarten. Child Dev. 2007;78(2):647-663.

16. Bandy T, Moore KA. Assessing Self-Regulation: A Guide for Out-ofSchool Time Program Practitioners. Washington, DC: Child Trends; 2010.

17. McClelland MM, Ponitz CC, Messersmith EE, Tominey S. Selfregulation: integration of cognition and emotion. In: Overton WF, Lerner RM, editors. The Handbook of Life-Span Development. 1st ed. Hoboken, NJ: Wiley; 2010:509-555.

18. King DL, Delfabbro PH, Doh YY, et al. Policy and prevention approaches for disordered and hazardous gaming and Internet use: an international perspective. Prev Sci. Epub 2017 July 4.

19. Király O, Griffiths MD, King DL, et al. Policy responses to problematic video game use: s systematic review of current measures and future possibilities. J Behav Addict. 2017:1-15.

20. Kumpfer KL, Alvarado R. Family-strengthening approaches for the prevention of youth problem behaviors. Am Psychol. 2003;58(6-7):457-465.

21. Kajonboon N. Effects of Computer Games - Addicted Preventive Program by Applying Cooperative Learning Method of Student Teams -Achievement Divisions on Prathom Suksa Five Students [master's thesis]. Bangkok: Chulalongkorn University; 2008.

22. Phosuwan N. Causal Factors Affecting Game Addiction Among Adolescents. Bangkok: National Institute of Development Administration (NIDA); 2009.
23. Pornnoppadol C, Sornpaisarn B, Khamklieng K, Pattana-amorn S. The Development of Game Addiction Screening Test (GAST). J Psychiatr Assoc Thailand. 2014;59(1):3-14.

24. Pornnoppadol C, Ladawan Na Ayudhaya S, Surapongphiwattana T, Phoasavasdi C. Identifying Protective Factors for Game Addiction in Children and Adolescents. Bangkok: National Research Council of Thailand; 2009.

25. Bandura A. Social cognitive theory of self-regulation. Organ Behav Hum Decis Process. 1991;50(2):248-287.

26. Baumeister RF, Vohs KD. Self-regulation, ego depletion, and motivation. Soc Personal Psychol Compass. 2007;1(1):115-128.

27. Baumeister RF, Gailliot M, DeWall CN, Oaten M. Self-regulation and personality: how interventions increase regulatory success, and how depletion moderates the effects of traits on behavior. J Pers. 2006;74(6):1773-1801.

28. Kanfer FH. Self-monitoring: methodological limitations and clinical applications. J Consult Clin Psychol. 1970;35(2):148-152.

29. Ferland F, Ladouceur R, Vitaro F. Prevention of problem gambling: modifying misconceptions and increasing knowledge. J Gambl Stud. 2002;18(1):19-29.

30. Williams RJ, Wood RT, Currie SR. Stacked Deck: an effective, schoolbased program for the prevention of problem gambling. J Prim Prev. 2010;31(3):109-125.

31. Seenuan C, Lagampan S, Powwattana A, Tongvichean S. Effect of family task program for game addiction prevention in children. J Ment Health Thailand. 2012;18(1):45-55.

32. Joo A, Park I. [Effects of an empowerment education program in the prevention of internet games addiction in middle school students]. J Korean Acad Nurs. 2010;40(2):255-263. Korean [with English abstract].

33. Kolkijkovin V, Wisitpongaree C, Techakasem P, Pornnoppadol C, Supawattanabodee B. Computer game addiction: risk and protective factors in students in Dusit District, Bangkok. Vajira Med J. 2015;59(3):1.

34. Thongkambunjong W, ChooChom O, Intasuwan P, Supparerkchaisakul N. Causal factors and effect of internet dependency behavior of high school students in Bangkok Metropolis. J Behav Sci. 2011;17(2):103-119.

35. Seay AF, Kraut RE. Project massive: Self-regulation and problematic use of online gaming. Poster presented at: Proceedings of the SIGCHI Conference on Human Factors in Computing Systems; April 28-May 03; 2007; San Jose, CA.

36. Billieux J, Van der Linden M. Problematic use of the Internet and self-regulation: a review of the initial studies. Open Addict J. 2012;5:24-29.

37. Cohen J. Statistical Power Analysis for the Behavioral Sciences. 2nd ed. Hilsdale, NJ: Lawrence Earlbaum Associates; 1988.

38. Mun SY, Lee BS. [Effects of an integrated internet addiction prevention program on elementary students' self-regulation and internet addiction]. J Korean Acad Nurs. 2015;45(2):251-261. Korean [with English abstract].
Psychology Research and Behavior Management

\section{Publish your work in this journal}

Psychology Research and Behavior Management is an international, peerreviewed, open access journal focusing on the science of psychology and its application in behavior management to develop improved outcomes in the clinical, educational, sports and business arenas. Specific topics covered in the journal include: Neuroscience, memory and decision making; Behavior modification and management; Clinical applications; Business and sports performance management; Social and developmental studies; Animal studies. The manuscript management system is completely online and includes a very quick and fair peer-review system, which is all easy to use. Visit http://www. dovepress.com/testimonials.php to read real quotes from published authors. 